Douglas A. Arenberg $\cdot$ Michael P. Keane

Bruno DiGiovine $\cdot$ Steven L. Kunkel

Scott R. B. Strom · Marie D. Burdick

Mark D. Iannettoni · Robert M. Strieter

\title{
Macrophage infiltration in human non-small-cell lung cancer: the role of CC chemokines
}

Received: 12 November 1999 / Accepted: 10 December 1999

\begin{abstract}
Bronchogenic carcinoma is the leading cause of malignancy-related mortality in the United States, with an overall 5 -year survival rate of less than $15 \%$. This aggressive behavior reflects, among other traits, the capacity of the tumor to evade normal host immune defenses, and to induce a pro-angiogenic environment. A central feature of any immune response toward tumors is the recruitment of specific immune cell populations. In the present study we investigated the infiltration of monocytes in human specimens of non-small-cell lung cancer (NSCLC). The presence of macrophages in NSCLC tumors was documented by immunohistochemistry. In vitro chemotaxis assays demonstrated higher monocyte chemotactic activity in NSCLC tumor homogenates than in normal lung tissue. We next investigated the expression of $\mathrm{CC}$ chemokines within
\end{abstract}

D. A. Arenberg $(\bowtie) \cdot$ M. P. Keane $\cdot$ S. R. B. Strom M. D. Burdick

University of Michigan Medical Center,

Division of Pulmonary and Critical Care,

6301 MSRB III, Box 0642,

1150 W. Medical Center Drive,

Ann Arbor, MI 48109, USA

Tel.: + 1-734-936-2612

Fax: + 1-734-764-4556

e-mail: darenber@umich.edu

B. DiGiovine

Henry Ford Hospital,

Division of Pulmonary Medicine,

Detroit, Mich., USA

S. L. Kunkel

University of Michigan Medical Center,

Department of Pathology, Ann Arbor, Mich., USA

M. D. Iannettoni

University of Michigan Medical Center,

Department of Surgery, Ann Arbor, Mich., USA

R. M. Strieter

Department of Medicine,

Division of Pulmonary and Critical Care Medicine,

University of California Los Angeles (UCLA),

Los Angeles, Calif., USA specimens of NSCLC tumors. Levels of the CC chemokines were higher in NSCLC tumor tissue than in normal lung tissue. Immunolocalization showed that the cells associated with antigenic CC chemokines were the malignant tumor cells, as well as occasional stromal cells. Maximal inhibition of monocyte chemotaxis induced by NSCLC in vitro occurred in the presence of neutralizing antibodies to MCP-1 and MIP-1 $\beta$. On follow-up of 15 patients in whom we quantified macrophage infiltration, we found that those with recurrence of disease had higher levels of macrophage infiltration in their initial tumors. However, the functional significance of CC-chemokine-mediated macrophage infiltration into NSCLC remains to be determined.

Key words Macrophage $\cdot$ Chemokine $\cdot$ Tumor

\section{Introduction}

Efforts at improving the poor prognosis of patients with non-small-cell lung cancer (NSCLC) depend, in part, upon a better understanding of the biology of lung cancer. One important aspect of this biology is the nature of interactions between malignant cells and the associated host cells within the tumor. Macrophages may constitute an important interface between tumor cells and the immune system. The role of macrophages in cancer has been studied with conflicting results. For example, different studies have found that macrophages can promote [1, 24, 35], or inhibit [24, 27] tumor growth, or exert cytostatic activity on growing tumor cells [3]. In this study we investigated the nature of macrophage infiltration into tumors, and hypothesize that tumorassociated macrophages may be recruited by local expression of macrophage chemotactic factors in NSCLC. Evidence suggesting active recruitment of macrophages to the site of a tumor would support the hypothesis that macrophages are capable of promoting tumor growth.

The chemokines represent a superfamily of chemotactic cytokines that recruit and activate sub-popula- 
tions of leukocytes. They are further classified into $\mathrm{CC}$, $\mathrm{CXC}, \mathrm{CX}_{3} \mathrm{C}$, and $\mathrm{C}$ families based upon the configuration of cysteine amino acid residues in the $\mathrm{NH}_{2}$ terminus. Macrophage recruitment is induced primarily by members of the CC chemokine family.

In the present study we evaluated patients with NSCLC at the University of Michigan Medical Center. We investigated the infiltration of macrophages relative to the content of specific CC chemokines (MCP-1, MIP$1 \alpha$, MIP-1 $\beta$, and RANTES) from the NSCLC tissue. Our results demonstrated that NSCLC tumors are markedly infiltrated with macrophages. Chemotaxis assays were performed with tumor homogenates to determine their ability to induce monocyte migration. These results demonstrated marked chemotactic activity in tumor homogenates relative to that in normal lung tissue. Furthermore, we found higher levels of CC chemokines in tumor tissue than in normal lung tissue. Immunolocalization of CC chemokines in NSCLC tissue revealed tumor cell localization of $\mathrm{CC}$ chemokine protein. Enumeration of infiltrating macrophages revealed a strong correlation with the levels of CC chemokines present in the corresponding tumor homogenate. Chemotaxis assays in the presence and absence of specific neutralizing antisera revealed that inhibition of chemotaxis was maximal in the presence of neutralizing antibodies to MCP-1 and MIP-1 $\beta$.

Our findings suggest that the presence of macrophages in advanced human lung cancer is due to the expression of $\mathrm{CC}$ chemokines in the tumor. However, the activation of these immune cells may be inadequate for a successful immune response against the tumor. In addition, it is possible that recruited macrophages benefit the tumors by elaborating molecules such as growth factors or angiogenic factors.

\section{Materials and methods}

Tissue specimens

Lung tissue specimens were obtained in a prospective fashion from consecutive patients undergoing thoracotomy for suspected primary bronchogenic carcinoma. All studies involving human tissues received prior approval of the University of Michigan's Institutional Review Board in accordance with the declaration of Helsinki. Normal lung specimens were obtained from a resected area of normal lung distal to the tumor. After recovery from the operating room, tissue samples were sectioned and two $6-\mathrm{mm}^{3}$ sections of tissue were homogenized in Complete anti-protease buffer (Boehringer Mannheim, Mannheim Germany) and sonicated. The aqueous extract of the tumor was frozen for later analysis by specific enzyme-linked immunosorbent assay (ELISA). Additional portions of some specimens were fixed in $4 \%$ paraformaldehyde for $24 \mathrm{~h}$, transferred to $70 \%$ ethanol, and subsequently embedded in paraffin. Pathological diagnoses were determined by a review of specimen slides by University Hospital pathologists. Only specimens with a final diagnosis of primary bronchogenic carcinoma were included in our study, with further classification of squamous cell or adenocarcinoma histology. "Normal" specimens were excluded from use in chemotaxis assays if the corresponding histological section revealed tumor or significant inflammation as indicated by leukocyte infiltration.

\section{Reagents}

Polyclonal antisera specific for human MCP-1, MIP- $1 \alpha$ and MIP$1 \beta$ were produced in our laboratories by the immunization of rabbits with human recombinant MIP- $1 \alpha$ and MIP-1 $\beta$ (R\&D Systems, Minneapolis, Minn.) or MCP-1 (Pepro Tech Inc., Rocky Hill, N.J.), in multiple intradermal sites with complete Freund's adjuvant. The specificity of each of these antibodies was assessed by Western blot analysis against a panel of other human recombinant cytokines. A commercial neutralizing polyclonal goat anti-(human RANTES) antibody was also employed (R\&D Systems, Minneapolis, Minn.). All antibodies were specific in a sandwich ELISA, and without cross-reactivity to a panel of 12 human recombinant interleukins (IL), including interleukin-1 receptor antagonist protein (IRAP), IL-1, IL-2, IL-4, IL-6, tumor necrosis factor $\alpha$ (TNF $\alpha)$, interferon $\gamma($ IFN $\gamma)$, and members of the CXC chemokine family. The neutralizing capacity of our rabbit antibodies has been characterized and a 1:1000 dilution of antiserum will neutralize the chemotactic activity of $30 \mathrm{ng} / \mathrm{ml}$ specific chemokine in a Boyden chamber chemotaxis assay. All antiserum titers were tested in direct ELISA and found to detect bound antigen at a dilution of $1: 10^{6}$. HAM-56 monoclonal antibody to human macrophages was purchased from Enzo Diagnostics (New York, N.Y.). The relevant isotype antibody or pre-immune serum was used as the control for immunohistochemistry or chemotaxis experiments.

Immunohistochemical localization of chemokines or macrophages

Paraffin-embedded tumor and normal lung tissue were processed for immunohistochemical localization of $\mathrm{CC}$ chemokines, using a modification of our previously described technique [40]. Briefly, tissue sections were de-waxed with xylene and rehydrated through graded concentrations of ethanol. Tissue nonspecific binding sites were then blocked by normal goat serum (normal rabbit serum for RANTES staining; BioGenex, San Ramon, Calif.). Tissue sections were then washed and incubated with primary antisera to human $\mathrm{CC}$ chemokines or human macrophages (1:500 dilution for rabbit antisera to MCP-1, MIP-1 $\alpha$, MIP-1 $\beta ; 1: 400$ for goat anti-RANTES and pre-diluted HAM-56 antibody from Enzo diagnostics), or equal dilutions of pre-immune serum for chemokine antibodies. The tissue sections were washed and then incubated for $60 \mathrm{~min}$ with biotinylated secondary antibodies (BioGenex, San Ramon, Calif.). Sections were then washed twice in TRIS-buffered saline and incubated with alkaline phosphatase conjugated to streptavidin (BioGenex, San Ramon, Calif.). Fast Red (BioGenex, San Ramon, Calif.) reagent was used for chromogenic localization of antigen in phosphatase-stained sections. After optimal color development, tissue sections were immersed in sterile water, counterstained in hematoxylin (macrophage-stained sections were counterstained lightly to facilitate cell counting), and cover-slipped, using an aqueous mounting solution.

\section{Cytokine ELISA}

Antigenic MCP-1, MIP- $1 \alpha$, MIP-1 $\beta$ and RANTES were measured by a modification of a double-ligand method, as previously described [7, 14]. Briefly, flat-bottomed 96-well plates were coated with the appropriate polyclonal antibodies. Nonspecific binding sites were blocked with $2 \%$ bovine serum albumin in phosphatebuffered saline. Test samples (undiluted and 1:10 diluted) were added $(50 \mu \mathrm{l} /$ well $)$ for $1 \mathrm{~h}$ at $37^{\circ} \mathrm{C}$. Plates were washed, biotinylated polyclonal antisera to human MCP- 1 , MIP- $1 \alpha$, MIP- $1 \beta$, or RANTES were added at $50 \mu \mathrm{l} /$ well, and the plates were incubated for $45 \mathrm{~min}$ at $37^{\circ} \mathrm{C}$. The plates were then washed three times, streptavidin-peroxidase conjugate (Bio-Rad Laboratories, Richmond, Calif.) was added, and the incubation was continued for $30 \mathrm{~min}$ at $37^{\circ} \mathrm{C}$. Plates were washed three times and chromogen substrate (Bio-Rad Laboratories, Richmond, Calif.) was added. The plates were incubated at room temperature to the desired absorbance, and the reaction was terminated with $50 \mu \mathrm{l} /$ well $3 \mathrm{M}$ 
$\mathrm{H}_{2} \mathrm{SO}_{4}$ solution. Plates were read at $490 \mathrm{~nm}$ in an automated microplate reader (Bio-Tek Instruments Inc., Winooski, Vt.). Standards were dilutions of recombinant interleukins from $100 \mathrm{ng}$ to $1 \mathrm{pg} / \mathrm{ml}(50 \mu \mathrm{l} /$ well $)$. This ELISA method consistently detected specific cytokine concentrations greater than $50 \mathrm{pg} / \mathrm{ml}$ in a linear fashion. All tissue homogenate specimens were run in parallel to determine the total protein content (Pierce, Rockford, Ill.), and results are expressed as nanograms of cytokine per milligram of protein.

\section{Chemotaxis}

In vitro monocyte chemotaxis was performed in modified Boyden chambers (Neuroprobe. Cabin John, Md.) as previously described [20, 41, 42]. Peripheral blood mononuclear cells were isolated from heparinized whole blood by Ficoll-Hypaque gradient centrifugation. The bottom wells of blind-well chemotaxis chambers were filled with test samples (NSCLC tumor homogenate or normal lung) with either neutralizing CC chemokine antibody or control serum (1:500 dilution, heat-inactivated). Filters were placed over the wells and the top wells were filled with freshly isolated human peripheral blood mononuclear cells (normal donor, $3 \times 10^{6}$ cells $/ \mathrm{ml}$ ) $[20,41,42]$. Chambers were placed in humidified, $37{ }^{\circ} \mathrm{C}, 5 \% \mathrm{CO}_{2}$ incubators for $1.5 \mathrm{~h}$. Filters were then removed, stained, and mounted on slides. Migrated cells were counted in five high-power fields per well. Each condition was run in triplicate, and the experiments were repeated three times. Results were expressed as mean \pm SEM of cells per high-power field.

\section{Statistical analysis}

Data were analyzed on a Macintosh computer using the Statview 4.5 statistical package (Abacus Concepts Inc., Berkeley, Calif.). Student's $t$-test was used to compare groups of data in chemotaxis experiments. Results for tumor and normal tissue were compared by the Mann-Whitney $U$-test. Comparisons between histological subtypes of NSCLC were performed with the Kruskall-Wallis test. Data were expressed as means \pm SEM. Data were considered statistically significant if $P$ values were less than or equal to 0.05 .

Fig. 1A-D Representative staining demonstrating patterns of macrophage (HAM56 antibody) infiltration in human non-small-cell lung cancer specimens. A Adenocarcinoma (original magnification $125 \times$ ). B Control staining of corresponding section (pre-immune serum, 125x). C Squamous cell carcinoma (original magnification $125 \times$ ). D Staining of the same section with pre-immune control serum

\section{Results}

\section{Macrophages are present throughout NSCLC tumors}

In order to characterize the presence of macrophage infiltration in NSCLC tumors, we performed immunohistochemical staining of the tumors with HAM-56 monoclonal antibody. Consistent with the findings of other authors [13, 25], we found a significant number of infiltrating macrophages in NSCLC tumors. Macrophages were found throughout all tumors in a diffuse and heterogeneous distribution (Fig. 1).

\section{NSCLC homogenates are chemotactic for monocytes}

To determine whether tumors were capable of actively recruiting mononuclear cells, we performed in vitro chemotaxis assays on tumor homogenates, using peripheral blood mononuclear cells from normal donors. Tumor homogenates were very potent in eliciting monocyte chemotaxis. Chemotaxis induced by adenocarcinoma and squamous carcinoma was 6.6- and 9.9- fold higher than that induced by control normal lung homogenate, standardized to total protein (Fig. 2, $P<0.001)$. Interestingly, the monocyte chemotactic activity of squamous cell carcinoma was 1.5 -fold greater than that of adenocarcinoma $(P=0.05)$.

\section{$\mathrm{CC}$ chemokine levels are increased in tumor tissue}

Since the primary chemoattractants for mononuclear cells are CC chemokines, we hypothesized that levels of $\mathrm{CC}$ chemokines would be higher in NSCLC tumors than
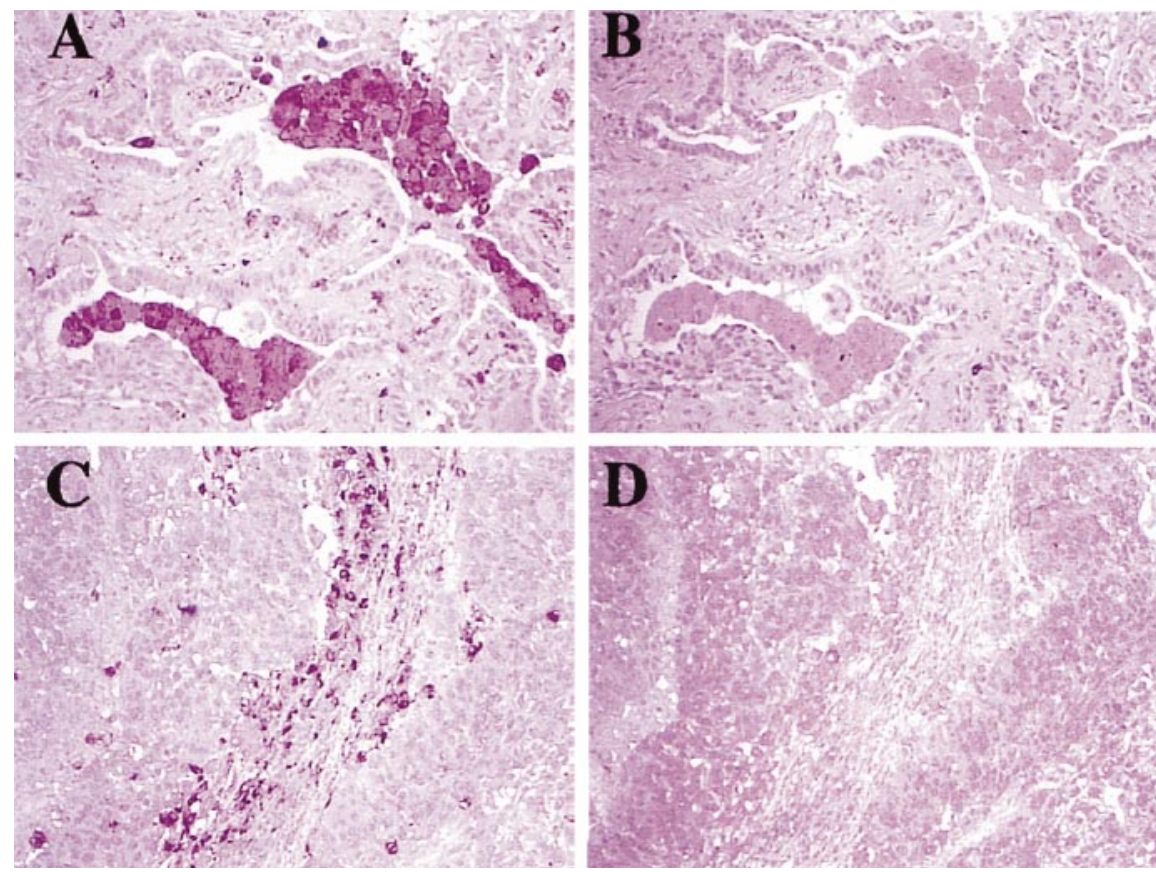
in normal lung tissue. Lung tissue homogenates were assayed for several CC chemokines by specific ELISA. Results were normalized to total protein (ng chemokine/ mg total protein) to allow for standardization of tumor samples compared to normal lung tissue. Our results

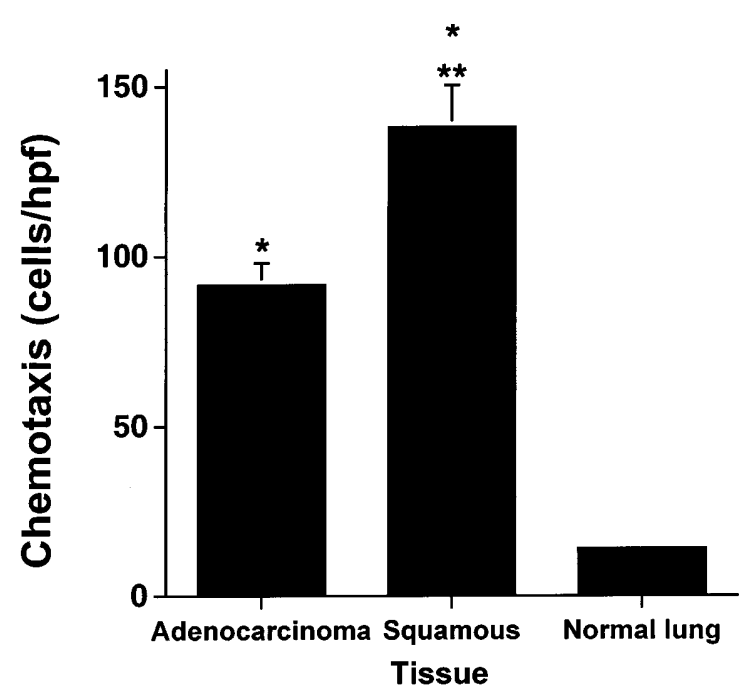

Fig. 2 Monocyte chemotactic activity of normal lung tissue, as compared to a denocarcinoma and squamous carcinoma lung cancer tissue. ${ }^{*} P<0.01$ for the comparison with normal lung, ** $P<0.05$ for the comparison between adenocarcinoma and squamous cell carcinoma demonstrated higher levels of CC chemokines in tumor tissue than in normal tissue (Table 1). Specifically, mean levels of MCP-1 in tumor samples were $2.24 \pm 0.53 \mathrm{ng} /$ $\mathrm{mg}$ total protein, compared to $1.04 \pm 0.41 \mathrm{ng} / \mathrm{mg}$ found in normal tissue $(P=0.04)$. MIP- $1 \alpha$ levels in tumor were $2.09 \pm 0.46 \mathrm{ng} / \mathrm{mg}$ compared to $1.05 \pm 0.41$ in normal lung $(P=0.05)$. MIP-1 $\beta$ levels in tumor were $1.92 \pm 0.34$ compared to $0.66 \pm 0.35 \mathrm{ng} / \mathrm{mg}$ in normal lung tissue $(P=0.005)$ and RANTES levels in tumor and normal tissue were $12.31 \pm 3.99$ and $6.99 \pm$ $1.68 \mathrm{ng} / \mathrm{mg}$ respectively $(P=0.05)$. Subgroup analysis demonstrated higher levels of MIP- $1 \alpha$ in squamous cell carcinoma than in adenocarcinoma, and a trend toward higher levels of other $\mathrm{CC}$ chemokines in squamous cell carcinoma than in adenocarcinoma.

We next employed immunohistochemical staining to localize antigenic CC chemokines in NSCLC tumors. Throughout all NSCLC tumors examined, chemokine immunoreactivity was predominantly associated with malignant cells, but also found in scattered stromal cells as well as in a pattern that suggested binding to the extracellular matrix (Fig.3).

CC chemokine expression correlates with macrophage infiltration

On the basis of the above findings, we expected that the degree of tumor infiltration by macrophages would
Table 1 Levels of CC chemokines in non-small-cell lung cancer tumor tissue, and in adenocarcinoma compared to squamous cell carcinoma

\begin{tabular}{llllr}
\hline Tissue & $\begin{array}{l}\text { MCP-1 } \\
(\mathrm{ng} / \mathrm{mg})\end{array}$ & $\begin{array}{l}\text { MIP-1 } \alpha \\
(\mathrm{ng} / \mathrm{mg})\end{array}$ & $\begin{array}{l}\text { MIP-1 } \beta \\
(\mathrm{ng} / \mathrm{mg})\end{array}$ & \multicolumn{1}{l}{$\begin{array}{l}\text { RANTES } \\
(\mathrm{ng} / \mathrm{mg})\end{array}$} \\
\hline Normal lung $(n=25)$ & $1.04 \pm 0.41$ & $1.05 \pm 0.41$ & $0.66 \pm 0.35$ & $6.99 \pm 1.68$ \\
Tumor tissue $(n=93)$ & $2.24 \pm 0.53^{*}$ & $2.09 \pm 0.46^{*}$ & $1.92 \pm 0.34^{*}$ & $12.31 \pm 3.99^{*}$ \\
Squamous cell $(n=38)$ & $2.50 \pm 0.70^{*}$ & $3.19 \pm 0.86^{*, * *}$ & $2.48 \pm 0.70^{*}$ & $11.13 \pm 3.33$ \\
Adenocarcinoma $(n=55)$ & $2.05 \pm 0.76$ & $1.33 \pm 0.49$ & $1.54 \pm 0.31^{*}$ & $13.101 \pm 6.30$ \\
\hline
\end{tabular}

$* P \leq 0.04$ for the comparison with normal lung tissue

** $P=0.05$ for the comparison between adenocarcinoma and squamous-cell carcinoma
Fig. 3A-D Representative photomicrographs of alkalinephosphatase immunolocalization of CC chemokines in specimens of non-small-cell lung cancer. A MCP-1 (original magnification $200 \times$ ), B MIP- $1 \alpha$ (original magnification 200 $\times$ ), $\mathbf{C}$ MIP-1 $\beta$ (original magnification $400 \times$ ), and D RANTES (original magnification $400 \times$ ). Control staining with pre-immune serum (for MIP-1a, MIP-1 $\beta$, and MCP-1) or goat IgG (for RANTES) demonstrated the absence of non-specific staining (data not shown)
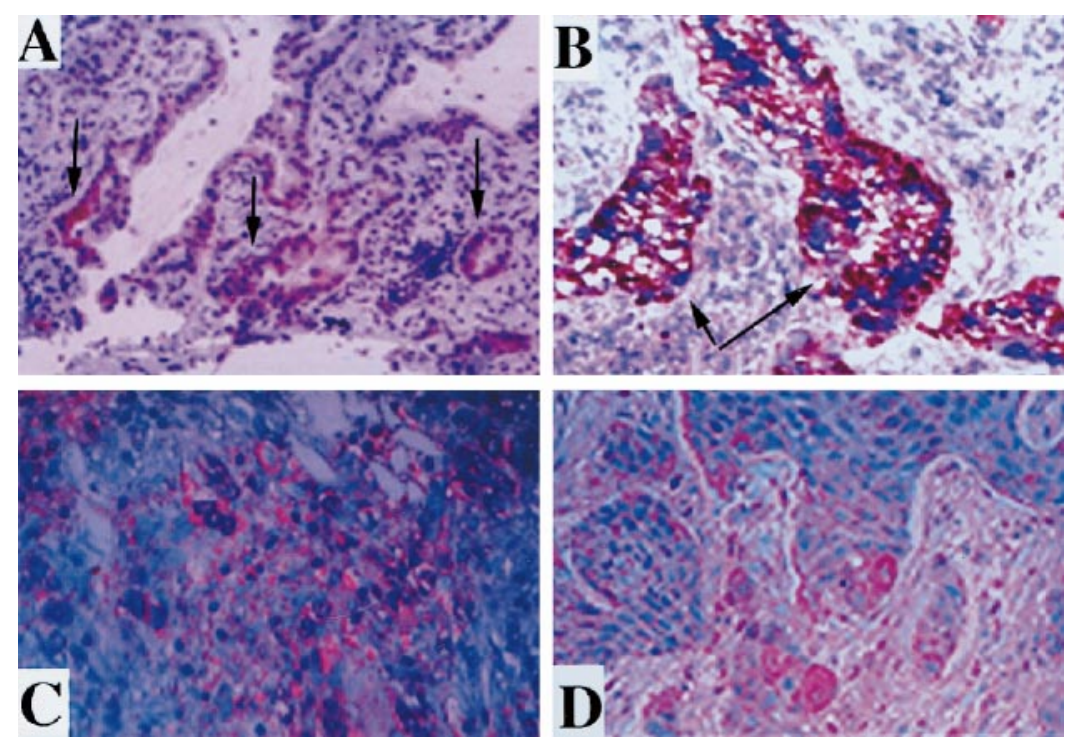
correlate with the level of chemotactic cytokines present in the tumors. There was a highly significant correlation between macrophage infiltration and levels of the individual chemokine, MIP-1 $\beta$, in the corresponding tumor $\left(r^{2}=0.45, P=0.03\right.$; data not shown). Levels of MCP-1 also correlated with macrophage infiltration $\left(r^{2}=0.50, P=0.02\right.$; data not shown). However, there was no significant correlation of macrophage infiltration with MIP- $1 \alpha$ and RANTES. When the numbers of macrophages per high power field were compared with the sum of all the CC chemokine levels measured, there was a significant and direct correlation $\left(r^{2}=0.71\right.$, $P=0.001$; Fig. 4). Clinical follow-up data on mortality were available for 15 of the 16 patients in whom we assessed macrophage infiltration. Interestingly patients who died $(n=7)$ had significantly greater numbers of macrophages than did patients who remained free of recurrence $(n=8 ; 92.3 \pm 19.8$ compared to $49.2 \pm 6.6$ macrophages per high power field, $P<0.05$; average follow-up time 76 months; Table 2)

NSCLC-induced monocyte chemotaxis is mediated by specific $\mathrm{CC}$ chemokines

In order to determine the contribution of $\mathrm{CC}$ chemokines to NSCLC-induced monocyte chemotaxis, specific

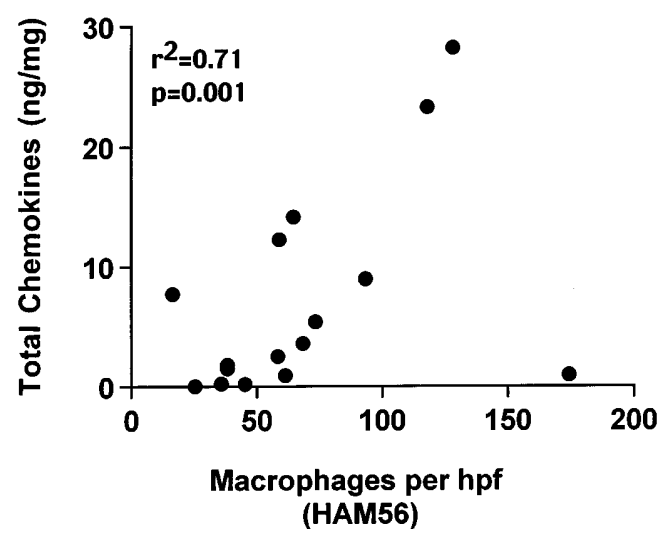

Fig. 4 Correlation of macrophage infiltration in histological sections of non-small-cell lung cancer (as assessed by HAM-56 immunostaining) with total CC chemokine levels (MCP-1, MIP-1 $\alpha$, MIP-1 $\beta$, and RANTES) in the corresponding tumor homogenate $\left(r^{2}=0.71, P=0.001\right)$

Table 2 Clinical follow-up data on 15 patients in whom we assessed macrophage infiltration. Patients who died $(n=7)$ had significantly greater numbers of macrophages than did patients who remained free of recurrence $(n=8,92.3 \pm 19.8$ versus $49.2 \pm 6.6$ macrophages/high-power field, $P<0.05$. Average follow-up time 76 months)

\begin{tabular}{ll}
\hline Outcome & $\begin{array}{l}\text { Macrophages (HAM 56) per } \\
\text { high-power field }\end{array}$ \\
\hline Dead $(n=7)$ & $92.3 \pm 19.8$ \\
Surviving $(n=8)$ & $49.2 \pm 6.6$ \\
\hline
\end{tabular}

neutralizing antibodies were employed in the chemotaxis assays. There was a marked difference between adenocarcinoma and squamous cell carcinoma in the degree of inhibition of monocyte chemotaxis achieved with neutralizing antibodies (Fig. 5). In the case of squamous cell carcinoma, the greatest inhibition of monocyte chemotaxis was seen with the addition of anti-MCP-1, whereas anti-MIP-1 $\beta$ was a more potent inhibitor of adenocarcinoma-induced monocyte chemotaxis. In addition, in contrast to squamous cell carcinoma, neutralization of MIP- $1 \alpha$ had no effect on monocyte chemotaxis in samples of adenocarcinoma. Neutralization of RANTES had a modest inhibitory effect on mononuclear cell chemotactic activity of NSCLC.

\section{Discussion}

In the present study we evaluated macrophage infiltration of human bronchogenic carcinoma. We found that tumors were infiltrated with macrophages in a diffuse, but non-homogeneous fashion. In addition, homogenates of NSCLC induced potent monocyte chemotactic activity. Overall, levels of $\mathrm{CC}$ chemokines were higher in the NSCLC tumors than in normal lung tissue. Associated with this increase in $\mathrm{CC}$ chemokine expression, we found histological evidence that tumors were infiltrated with macrophages to a degree that correlated with CC chemokine expression. Furthermore, we found that squamous cell carcinoma was associated with higher levels of MIP- $1 \alpha$ than was adenocarcinoma. This trend was paralleled by the fact that squamous cell carcinoma homogenates elicited a greater monocyte chemotactic response than did adenocarcinoma homogenates. We then found that the monocyte chemotactic activity could

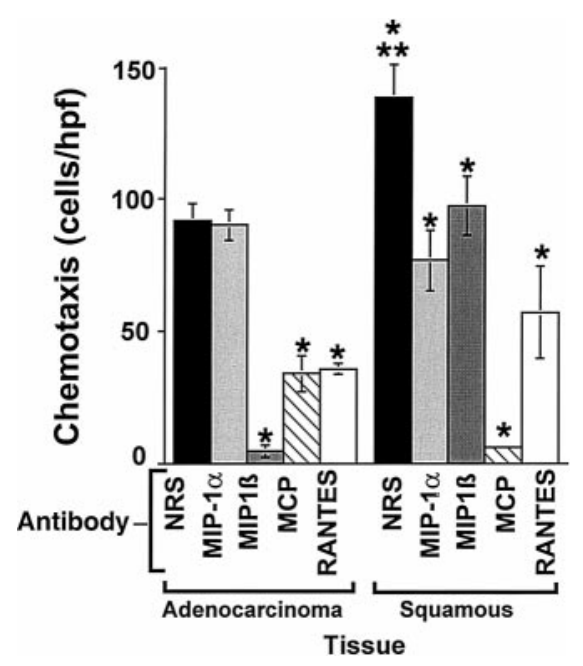

Fig. 5 Monocyte chemotaxis induced by adenocarcinoma and squamous cell carcinoma lung cancer homogenates in the presence of specific neutralizing $\mathrm{CC}$ chemokine antibodies or control (normal rabbit serum, NRS). $* P<0.01$ compared to normal rabbit serum (NRS), $* * P<0.05$ for the comparison between adenocarcinoma and squamous cell carcinoma 
be almost entirely inhibited by the addition of neutralizing antibodies to $\mathrm{CC}$ chemokines. Furthermore, MIP$1 \beta$ and MCP-1, the chemokines that correlated most strongly with histological macrophage infiltration, also accounted for the majority of the chemotactic activity in NSCLC tumor homogenates. One caveat of our study is that the "normal lung tissue" we used was derived from patients undergoing thoracotomy for lung cancer. While we did exclude tissue that was infiltrated with inflammatory cells by histology, it is possible that the lungs of these patients, all former smokers, do not truly reflect "normal" tissue levels.

While we have not exhaustively evaluated the entire family of $\mathrm{CC}$ chemokines in relation to macrophage infiltration of NSCLC tumors, it is clear from our data that members of this family are expressed in high levels in tumors in a biologically active form. We cannot exclude the possibility that the chemotactic activity detected in tumor homogenates represents both secreted and intracellular chemokines. There is evidence that some chemokines are bound to glycosaminoglycans in the extracellular matrix via the carboxy-terminal heparin-binding domain [45]. The detection of antigenic protein, therefore, does not confirm secretion of the protein. However, the presence of a significant number of infiltrating macrophages suggests that tumors may actively recruit monocytes/macrophages into the local environment via expression of $\mathrm{CC}$ chemokines. Immunolocalization would suggest that the cells responsible for this $\mathrm{CC}$ chemokine expression are the malignant cells and scattered non-malignant cells within the stroma.

These findings may also be consistent with a local activation of the immune system reflecting an attempt to mount a tumor-specific immune response. Alternatively, the expression of chemokines within tumors may serve to attract macrophages, which may then provide support for tumor growth by several possible mechanisms. For example, Polverini and co-workers have shown that tumor-associated macrophages are potently angiogenic when isolated from experimental rat tumors [35]. More recent studies have found a correlation between macrophage infiltration and vessel density in ovarian [33], breast [22], and CNS malignancies [29]. Similarly, Acero and co-workers [1] found that macrophages actually promoted in vivo tumor formation in several murine sarcoma cell lines. If macrophages promote growth or a pro-angiogenic environment [37], then expression of CC chemokines, and consequent macrophage infiltration, may confer a survival advantage upon a population of tumor cells. That an inflammatory response may promote tumorigenesis is further supported by the findings of Moore et al., which demonstrate that mice deficient in $\mathrm{TNF} \alpha$ are less susceptible to formation of skin tumors [26]. In this same study, the authors reported that mice with deletion of the gene for MCP-1 were also less susceptible to skin tumor initiation [26].

While tumors may derive benefits from mononuclear cell infiltration, it is also clear that some tumors can be successfully contained and eradicated by immune cells
$[12,21,34]$. The key to this apparent paradox may be the capacity of some tumors to induce the influx of one population of immune cells selectively, without recruiting those cells that may exert antitumor effects. Alternatively, some tumors may recruit immune cells, but inhibit their ability to effect an antitumor response. In support of this contention, Vitolo and colleagues have found that tumor-derived lymphocytes fail to express "pro-inflammatory" cytokines in situ, despite evidence that they retain their ability to do so ex vivo when isolated from tumors [44]. In parallel with this, we have previously reported that NSCLC tumors express significant levels of the immunomodulatory cytokines, IL-1 receptor antagonist and IL-10 [38, 39]. This phenomenon, combined with the shedding of soluble tumorspecific antigens $[2,10,30,31]$ and reduced cell-surface expression of class I MHC antigens [9, 43], may provide the tumor with a defense against immune surveillance.

A possible mechanism allowing recruitment of a selective population of leukocytes is through the elaboration of appropriate chemotactic cytokines. The CC chemokine family is a group of cytokines that exert chemotactic and activating activity with a variety of immune cells including monocytes, lymphocytes, eosinophils, basophils, and stem cells. A great deal of contrasting evidence exists in the literature regarding the role or function of chemokines in malignancy. For example, some authors have found that increasing tumor cell expression of $\mathrm{CC}$ chemokines through various genetransfer strategies can lead to enhanced antitumor activity. Nakashima et al. have found that MIP- $1 \alpha$ gene transfer into colon adenocarcinoma cells reduced the tumor-forming potential of these cells compared to mock-transfected cells [27]. Similarly, Rollins and colleagues [36] as well as Huang and co-workers [18] found that gene transfer of murine-JE/MCP-1 (a murine $\mathrm{CC}$ chemokine) suppressed the tumorigenic and metastatic potential of malignant cells. However, in a separate study, Hirose and colleagues found disparate effects of transfecting tumor cells with MIP- $1 \alpha$ and MCP-1 on their ability to form tumors in nude mice [17]. In their study, transfection of tumor cells with MIP- $1 \alpha$ was associated with a neutrophilic influx, and with reduced ability to form tumors. However, gene transfer of either human or murine MCP-1 did not inhibit the tumorforming potential of these cells. In a related study by Botazzi and colleagues, transfer of the MCP-1 gene into melanoma cells had disparate effects on tumor growth, depending on whether the number of cells inoculated was high (antitumor effects predominated), or low (protumor effects predominated) [6]. In this same study, MCP-1-expressing melanoma cells were less susceptible to the antitumor effects of IL-2 therapy [6].

In contrast to these strategies employing transfected tumor cells, our data, combined with previous work of other authors [5, 11, 28, 32] suggest that many tumors are already expressing significant levels of chemotactic cytokines. For example, constitutive expression of MCP-1 has been reported in human ovarian carcinoma 
[28] and glioma [11]. Interestingly, MCP-1 and its related chemokines, MCP-2 and MCP-3, were all originally cloned from malignant cell lines [5, 32]. Recently there has been experimental evidence that chemokines play a role in polarizing $\mathrm{T}$-helper immune responses along the Th1/Th2 axis. In particular, several authors have found that MCP-1 can promote the development of Th2 responses from naïve $\mathrm{T}$ cells $[8,16,19,23]$. These findings by other investigators suggest a mechanism of chemokine regulation of immune responses that a tumor might use to retard Th1-mediated antitumor responses. While this study was not designed to examine survival in relation to macrophage infiltration, the finding that patients who subsequently died of recurrent malignancy had greater degrees of macrophage infiltration in their tumors suggests that macrophages may be co-opted by tumors to support growth or metastasis.

Finally, recent work, using mice deficient in either MCP-1 (JE) [15], or its receptor CCR2 [4], suggests that macrophages play an important role in animal models of atherosclerosis. While atherosclerosis and tumor growth may appear to be very diverse in pathophysiology, these interesting findings suggest the importance of the monocyte/macrophage in disease states characterized by inappropriate tissue proliferation.

Given these contrasting data, it remains unclear whether expression of chemokines represents a feature of malignant cells that confers some survival advantage, or whether it represents an ineffective effort on the part of the host immune system to mount an antitumor response. The goal of future studies in this area should be to determine the mechanism by which these chemokines are expressed in tumors, as well as more precisely defining the consequences of macrophage infiltration in solid tumors.

Acknowledgements The authors thank Charity Olson for secretarial assistance. This work was supported, in part, by NIH grants CA72543 (D.A.A.), P50HL46487 and P50HL60289 (R.M.S., S.L.K), HL03906 (M.P.K.) and an American Lung Association research grant RG-065-N, (D.A.A.). Dr. Arenberg is a Sidney Kimmel Foundation Scholar.

\section{References}

1. Acero R, Polentarutti N, Bottazzi B, Alberti S, Ricci MR, Bizzi A, Mantovani A (1984) Effect of hydrocortisone on the macrophage content, growth and metastasis of transplanted murine tumors. Int J Cancer 33: 95

2. Alexander P (1974) Proceedings: escape from immune destruction by the host through shedding of surface antigens: is this a characteristic shared by malignant and embryonic cells? Cancer Res 34: 2077

3. Audran R, Dazord L, Toujas L (1994) Interactions between human macrophages and tumor cells in three- dimensional cultures. Cancer Immunol Immunother 39: 299

4. Boring L, Gosling J, Cleary M, Charo IF (1998) Decreased lesion formation in CCR2-/- mice reveals a role for chemokines in the initiation of atherosclerosis. Nature 394: 894

5. Bottazzi B, Colotta F, Sica A, Nobili N, Mantovani A (1990) A chemoattractant expressed in human sarcoma cells (tumorderived chemotactic factor, TDCF) is identical to monocyte chemoattractant protein-1/monocyte chemotactic and activating factor (MCP-1/MCAF). Int J Cancer 45: 795

6. Bottazzi B, Walter S, Govoni D, Colotta F, Mantovani A (1992) Monocyte chemotactic cytokine gene transfer modulates macrophage infiltration, growth, and susceptibility to IL-2 therapy of a murine melanoma. J Immunol 148: 1280

7. Burdick MD, Kunkel SL, Lincoln PM, Wilke CA, Strieter RM (1993) Specific ELISAs for the detection of human macrophage inflammatory protein-1 alpha and beta. Immunol Invest 22: 441

8. Chensue SW, Warmington KS, Ruth JH, Sanghi PS, Lincoln P, Kunkel SL (1996) Role of monocyte chemoattractant protein-1 (MCP-1) in Th1 (mycobacterial) and Th2 (schistosomal) antigen-induced granuloma formation: relationship to local inflammation, Th cell expression, and IL-12 production. J Immunol 157: 4602

9. Cohen EP, Kim TS (1994) Neoplastic cells that express low levels of MHC class I determinants escape host immunity. Semin Cancer Biol 5: 419

10. Davey GC, Currie GA, Alexander P (1976) Spontaneous shedding and antibody induced modulation of histocompatibility antigens on murine lymphomata: correlation with metastic capacity. Br J Cancer 33: 9

11. Desbaillets I, Tada M, Tribolet N de, Diserens AC, Hamou MF, Van Meir EG (1994) Human astrocytomas and glioblastomas express monocyte chemoattractant protein-1 (MCP1) in vivo and in vitro. Int J Cancer 58: 240

12. Edwards MJ, Anderson JA, Angel JR, Harty JI (1996) Spontaneous regression of primary and metastatic renal cell carcinoma. J Urol 155: 1385

13. Endress H, Freudenberg N, Fitzke E, Grahmann PR, Hasse J, Dieter P (1997) Infiltration of lung carcinomas with macrophages of the 27E10-positive phenotype. Lung Cancer 18: 35

14. Evanoff HL, Burdick MD, Moore SA, Kunkel SL, Strieter RM (1992) A sensitive ELISA for the detection of human monocyte chemoattractant protein-1 (MCP-1). Immunol Invest 21: 39

15. Gosling J, Slaymaker S, Gu L, Tseng S, Zlot CH, Young SG, Rollins BJ, Charo IF (1999) MCP-1 deficiency reduces susceptibility to atherosclerosis in mice that overexpress human apolipoprotein B. J Clin Invest 103: 773

16. Gu L, Rutledge B, Fiorillo J, Ernst C, Grewal I, Flavell R, Gladue R, Rollins B (1997) In vivo properties of monocyte chemoattractant protein-1. J Leukoc Biol 62: 577

17. Hirose K, Hakozaki M, Nyunoya Y, Kobayashi Y, Matsushita K, Takenouchi T, Mikata A, Mukaida N, Matsushima K (1995) Chemokine gene transfection into tumour cells reduced tumorigenicity in nude mice in association with neutrophilic infiltration. Br J Cancer 72: 708

18. Huang S, Singh RK, Xie K, Gutman M, Berry KK, Bucana CD, Fidler IJ, Bar-Eli M (1994) Expression of the JE/MCP-1 gene suppresses metastatic potential in murine colon carcinoma cells. Cancer Immunol Immunother 39: 231

19. Karpus WJ, Lukacs NW (1996) The role of chemokines in oral tolerance. Abrogation of nonresponsiveness by treatment with antimonocyte chemotactic protein-1. Ann N Y Acad Sci 778: 133

20. Kasama T, Strieter RM, Standiford TJ, Burdick MD, Kunkel SL (1993) Expression and regulation of human neutrophilderived macrophage inflammatory protein 1 alpha. J Exp Med 178: 63

21. Khar A, Muralikrishna K, Varalakshmi C (1997) High intratumoural level of cytokines mediates efficient regression of a rat histiocytoma. Clin Exp Immunol 110: 127

22. Leek RD, Landers RJ, Harris AL, Lewis CE (1999) Necrosis correlates with high vascular density and focal macrophage infiltration in invasive carcinoma of the breast. Br J Cancer 79: 991

23. Lukacs NW, Chensue SW, Karpus WJ, Lincoln P, Keefer C, Strieter RM, Kunkel SL (1997) C-C chemokines differentially alter interleukin-4 production from lymphocytes. Am J Pathol 150: 1861 
24. Mantovani A (1981) In vitro effects on tumor cells of macrophages isolated from an early-passage chemically-induced murine sarcoma and from its spontaneous metastases. Int $\mathbf{J}$ Cancer 27: 221

25. Mantovani A (1994) Tumor-associated macrophages in neoplastic progression: a paradigm for the in vivo function of chemokines. Lab Invest 71: 5

26. Moore RJ, Owens DM, Stamp G, Arnott C, Burke F, East N, Holdsworth H, Turner L, Rollins B, Pasparakis M, Kollias G, Balkwill F (1999) Mice deficient in tumor necrosis factoralpha are resistant to skin carcinogenesis. Nat Med 5: 828

27. Nakashima E, Oya A, Kubota Y, Kanada N, Matsushita R, Takeda K, Ichimura F, Kuno K, Mukaida N, Hirose K, Nakanishi I, Ujiie T, Matsushima K (1996) A candidate for cancer gene therapy: MIP-1 alpha gene transfer to an adenocarcinoma cell line reduced tumorigenicity and induced protective immunity in immunocompetent mice. Pharm Res 13: 1896

28. Negus RP, Stamp GW, Relf MG, Burke F, Malik ST, Bernasconi S, Allavena P, Sozzani S, Mantovani A, Balkwill FR (1995) The detection and localization of monocyte chemoattractant protein-1 (MCP-1) in human ovarian cancer. J Clin Invest 95: 2391

29. Nishie A, Ono M, Shono T, Fukushi J, Otsubo M, Onoue H, Ito Y, Inamura T, Ikezaki K, Fukui M, Iwaki T, Kuwano M (1999) Macrophage infiltration and heme oxygenase-1 expression correlate with angiogenesis in human gliomas (in Process Citation). Clin Cancer Res 5: 1107

30. Nordquist RE, Anglin JH, Lerner MP (1977) Antibody-induced antigen redistribution and shedding from human breast cancer cells. Science 197: 366

31. Nordquist RE, Anglin JH, Lerner MP (1978) Antigen shedding by human breast-cancer cells in vitro and in vivo. $\mathrm{Br} \mathrm{J}$ Cancer 37: 776

32. Opdenakker G, Froyen G, Fiten P, Proost P, Van Damme J (1993) Human monocyte chemotactic protein-3 (MCP-3): molecular cloning of the cDNA and comparison with other chemokines. Biochem Biophys Res Commun 191: 535

33. Orre M, Rogers PA (1999) Macrophages and microvessel density in tumors of the ovary. Gynecol Oncol 73: 47

34. Papac RJ (1996) Spontaneous regression of cancer. Cancer Treat Rev 22: 395

35. Polverini PJ, Leibovich SJ (1984) Induction of neovascularization in vivo and endothelial cell proliferation in vitro by tumor-associated macrophages. Lab Invest 51: 635
36. Rollins BJ, Sunday ME (1991) Suppression of tumor formation in vivo by expression of the JE gene in malignant cells. Mol Cell Biol 11: 3125

37. Shoji M, Hancock WW, Abe K, Micko C, Casper KA, Baine RM, Wilcox JN, Danave I, Dillehay DL, Matthews E, Contrino J, Morrissey JH, Gordon S, Edgington TS, Kudryk B, Kreutzer DL, Rickles FR (1998) Activation of coagulation and angiogenesis in cancer: immunohistochemical localization in situ of clotting proteins and vascular endothelial growth factor in human cancer. Am J Pathol 152: 399

38. Smith DR, Kunkel SL, Standiford TJ, Chensue SW, Rolfe MW, Orringer MB, Whyte RI, Burdick MD, Danforth JM, Gilbert AR, Strieter RM (1993) The production of interleukin1 receptor antagonist by human bronchogenic carcinoma. Am J Pathol 143: 794

39. Smith DR, Kunkel SL, Burdick MD, Wilke CM, Orringer MB, Whyte RI, Strieter RM (1994) Production of interleukin10 by human bronchogenic carcinoma. Am J Pathol 145: 18

40. Standiford TJ, Kunkel SL, Basha MA, Chensue SW, Lynch JP, Toews GB, Westwick J, Strieter RM (1990). Interleukin-8 gene expression by a pulmonary epithelial cell line: a model for cytokine networks in the lung. J Clin Invest 86: 1945

41. Standiford TJ, Rolfe MW, Kunkel SL, Lynch JPD, Burdick MD, Gilbert AR, Orringer MB, Whyte RI, Strieter RM (1993) Macrophage inflammatory protein-1 alpha expression in interstitial lung disease. J Immunol 151: 2852

42. VanOtteren GM, Standiford TJ, Kunkel SL, Danforth JM, Burdick MD, Abruzzo LV, Strieter RM (1994) Expression and regulation of macrophage inflammatory protein-1 alpha by murine alveolar and peritoneal macrophages. Am J Respir Cell Mol Biol 10: 8

43. Vegh Z, Wang P, Vanky F, Klein E (1993) Selectively downregulated expression of major histocompatibility complex class I alleles in human solid tumors. Cancer Res 53: 2416

44. Vitolo D, Zerbe T, Kanbour A, Dahl C, Herberman RB, Whiteside TL (1992) Expression of mRNA for cytokines in tumor-infiltrating mononuclear cells in ovarian adenocarcinoma and invasive breast cancer. Int Cancer 51: 573

45. Webb LM, Ehrengruber MU, Clark-Lewis I, Baggiolini M, Rot A (1993) Binding to heparan sulfate or heparin enhances neutrophil responses to interleukin 8. Proc Natl Acad Sci USA 90: 7158 